\title{
ジメチルエーテル拡散火炎の消炎特性に関する研究*
}

(第 1 報, 消炎特性に及ぼす平衡温度及び火炎構造の影響)

\author{
田上公 俊*1, 森秀 芳*2 \\ 田尻隆之草, 嶋田不美生*4
}

\section{Study of Extinction Properties in Dimethyl Ether Diffusion Flames (1st Report, Effects of Equilibrium Flame Temperature and Flame Structure on Extinction Properties)}

\author{
Kimitoshi TANOUE*5, Shuho MORI, \\ Takayuki TAJIRI and Fumio SHIMADA \\ ${ }^{* 5}$ Department of Mechanical Engineering, Oita University, \\ 700 Dannoharu, Oita-shi, Oita, 870-1192 Japan
}

\begin{abstract}
Recently many issues related to automotive engineering, such as the environment and energy problems have gained attention. These social-related issues are giving impetus to the adoption of urgent measures such as alternative fuels and new combustion techniques for the internal combustion engines. In this context, dimethyl ether is thought to be a potential alternative to diesel fuel, as it has lower overall pollutant emissions and better economy. On the other hand, oxygen-enriched combustion has been gaining acceptance as an environmental friendly combustion, because this can reduce soot and $\mathrm{NO}_{x}$ emission. The purposes of this paper are to examine the extinction properties of DME flames and the feasibility concerning the application of oxygen-enriched combustion to DME flames using a counterflow burner. Firstly, the strain rate at extinction is measured for dimethyl ether and propane flames as a function of equilibrium flame temperature under the same flame structure. Secondly, the strain rate at extinction is also measured under the condition that the flame structures are changed, but the equilibrium flame temperatures are not varied. In addition, numerical calculations are also performed using detailed chemical-kinetic mechanism to obtain value for extinction and compared with measurements.
\end{abstract}

Key Words : Diffusion Combustion, Extinction, Flame, Flammability Limit, DME

\section{1. 緒}

現在の内燃機関の燃焼技術には，社会的背景として 省エネルギー化を目的とした熱効率の向上と，二酸化 炭素 $\mathrm{CO}_{2}$ の温室効果ガスや窒素酸化物 $\mathrm{NO}_{x}$ などの環境 污染物質排出量の低減が求められている(1). また, 内 燃機関の然料には, エネルギ一資源枯渇問題と排気ガ スのクリーン化の観点からさまざまな代替燃料が検討 されている.とりわけ, ジメチルエーテル(2) (以下, DME と記す）は，最も低分子のエーテルであり，毒 性もメタノールに比べてかなり低く, 低排出ガス性と 良好な経済性から軽油代替燃料として近年注目されて

\footnotetext{
* 原稿受付 2008 年 4 月 4 日.

*1 正員, 大分大学工学部 (丞 870-1192 大分市旦野原 700).

*2 正員, 大分大学大学院環境工学専攻.

*3 学生員, 大分大学大学院機械・エネルギーシステム工学専 攻.

*4 大分大学工学部

E-mail : tanoue@cc.oita-u.ac.jp
}

いる ${ }^{(3)-(5)}$. DME の主な利点は, セタン価が 55 から 60 であり，また沸点がー $25^{\circ} \mathrm{C}$ であることから早い混合 気形成, 着火遅れの低減, 良好な始動性の実現が挙げ られる.また，含酸素燃料であることと炭素同士の結 合がないことから無煙な燃焼であり，同時に排気ガス 再循環（EGR）による燃焼温度制御により $\mathrm{NO}_{x}$ の削減 も期待できる.

一般にディーゼルエンジン内の燃焼は, 拡散燃焼が 支配的なため, 軽油代替燃料を実機に適用する場合, その拡散燃焼特性を把握する必要がある，中でも消炎 特性は, 燃料の高温酸化反応を体現した現象であるた め, 反応機構・燃焼モデルの構築および検証のための 重要な基礎データとなる ${ }^{(6)}$. さらに出力, 燃費, 排気 ガス特性などのエンジン特性に大きな影響を及ぼすこ とから, エンジン性能向上のためには消炎特性の把握 および而消炎特性の高い燃焼手法の開発が求められる. 
層流拡散火炎は，拡散然焼場での流れの特性時間 と化学反応の特性時間 $\boldsymbol{\tau}_{\mathrm{c}}$ の比で示されるダムケラー数 $D a\left(\equiv \tau_{f} \tau_{c}\right)$ が大きい場合，反応物は完全に消費される. しかしながら, 気流 (火炎伸張率) が堌すと, 流れの 特性時間が短くなり，ダムケラー数は减少する. ダム ケラー数が減少すると，反応物は完全に消費されない ため，火炎温度は低下する. さらにダムケラー数が減 少し，ある臨界ダムケラー数 $D a_{\mathrm{q}}$ に達すれば，不完全 反忘によりついは消炎に至る(6)( ${ }^{(6)}$ この場合， $D a_{q}$ は 火炎の耐消炎特性の程度を代表する値と考えることが できる.

消炎は，上述のような化学反応と気流（火炎伸張 率)の相対的関係だけではなく，ルイス数》で代表さ れる分子レベルの熱・物質拡散が大きな影響を及ぼす 複雑な現象であるため, これまで基䃈研究には, 実験 が比較的容易で, 明確な定量化が可能な対向流拡散火 炎が広く用いられてきだ。

対向流拡散火炎の消炎に関寸る研究は， $\mathrm{C}_{2} \mathrm{H}_{4}, \mathrm{C}_{2} \mathrm{H}_{6}$, $\mathrm{C}_{3} \mathrm{H}_{6}$ と $\mathrm{C}_{3} \mathrm{H}_{8}$ に関する Humer ら ${ }^{(9)}$ の研究, $\mathrm{CH}_{4}, \mathrm{C}_{2} \mathrm{H}_{4}$, $\mathrm{C}_{2} \mathrm{H}_{6}$ と $\mathrm{C}_{3} \mathrm{H}_{8}$ に関する Chen ら ${ }^{(10)}$ の研究, および $\mathrm{CH}_{4}-$ $\mathrm{O}_{2}-\mathrm{N}_{2}$ に関する $\mathrm{Du} ら^{(11)}$ の研究, $\mathrm{CH}_{4}$ に関する石塚ら ${ }^{(12)}$ や $\mathrm{C}_{3} \mathrm{H}_{8}$ に関する Puri ら ${ }^{(13)}$ の研究など，これまで多く の研究がなされているが，DME 拡散火炎の消资特性 に関する研究は見受けられない，

以上の背景から本研究は，対向流バーナによる実験 と詳細な化学反応を考慮した数值計算により, DME 拡散火炎の基礎的な消炎特性を解明するとともに，高 い耐消炎特性を有する新燃焼法を検討する，本論文で はまず，DME の消炎特性に及ぼす平衡温度および火 炎構造の影響を詳細に調べる.ここでは $\mathrm{C}_{3} \mathrm{H}_{8}$ の実験 結果と比較して DME の消炎特性を明らかにする. ま た, 高効率・環境低負荷な新燃焼法の一つとして提案

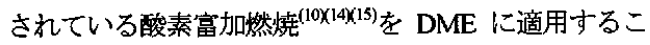
とを想定し, この場合に形成される火炎の火炎構造が DME の消炎特性に及ぼす影響を調へ，その燃焼機構 を詳細に調べる.

\section{2. 実験装酎および方法}

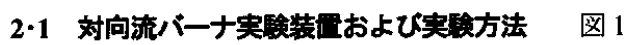
に本研究で用いる対向流バーナの概略図を示す. 対向 流バーナは過去の研究(9)(16) と同じであり, 図 1 に示市 ように上下 2 本のダクトから構成されており,ダクト 1 からは㜣料と窒素 $\mathrm{N}_{2}$ を, ダクト 2 からは酸素と窒素 $\mathrm{N}_{2}$ を噴出する. 周囲空気の影響を阻止するために, 各 ダクトを囲んで窒素 $\mathrm{N}_{2}$ のカーテン流が燃料流および 酸化剂流と平行に流れる. 実験での燃料，酸化剤およ

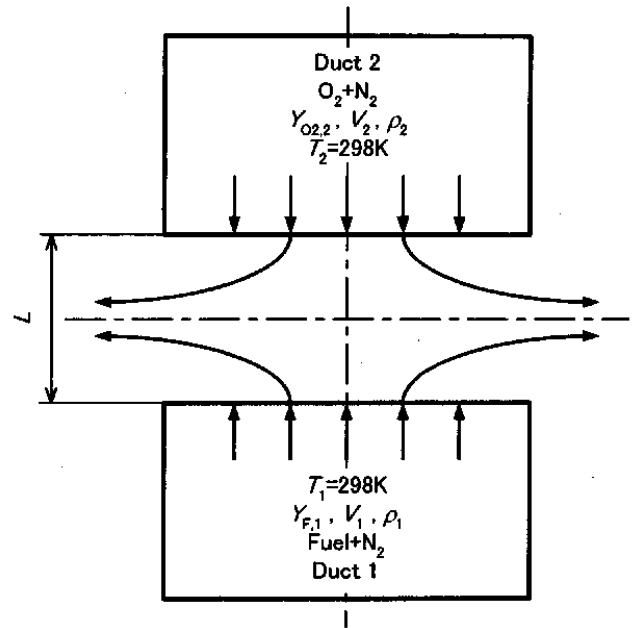

Fig. 1 Schematic Illustration of the Counterflow Configuration

び窒素 $\mathrm{N}_{2}$ の流量は, コンピュータ制御のマスフ ローコントローラ（Advanced Energy FC-780）で制御 する. マスフローコントローラの測定精度は $1 \%$ 以下 である. また, 本研究の場合, ダクト間の距離 $L$ は 8 $\mathrm{mm}$ とした。図 1 において $Y_{\mathrm{F}}, Y_{02}$ はそれぞれ然料と 酸素の質量分率， $V$ は流速， $T$ は温度， $\rho$ は密度であ り, 添字 1，2 はそれぞれダクト 1 , ダクト 2 の物理量 に対応する. 本研究ではダクト出口での接線方向流れ はないもの（Plug-flow boundary condition）と仮定し, 両ダクト出口流速 $V$ は体積流量とダクト出口面積の比 から算出した。

実験は大気圧下で行い，両ダクト間の中央部付近で よどみ面を形成させ，この近傍に伸張のある火炎が形 成される. このとき, 火炎伸張率 $a_{2}$ 恃次式から求める (17).

$$
a_{2}=\frac{2\left|V_{2}\right|}{L}\left(1+\frac{\left|V_{1}\right| \sqrt{\rho_{1}}}{\left|V_{2}\right| \sqrt{\rho_{2}}}\right)\left(\mathrm{s}^{-1}\right)
$$

この際，よどみ平面が両ダクト間の中央付近に形成さ れるように, 両ダクト出口での流体の運動量を以下の ように等しくした.

$$
\rho_{1} V_{1}^{2}=\rho_{2} V_{2}^{2}
$$

実験は, 上下のダクトから酸化放, 燃料を噴出し点 火させ, 火炎を形成後, 火炎伸張率 $a_{2}$ を変化させなが ら，火炎を観察し，消炎する条件を特定した。

$2 \cdot 2$ 火炎パラメータ 拡散燃焼場では, 火炎構 造の指標になる混合層 (mixing layer) 内の相対的な位 置は, 以下の mixture fraction, $Z$ により表すことがで きる(6). 


$$
Z=\frac{Y_{\mathrm{F}} / W_{\mathrm{F}} v_{\mathrm{F}}+\left(Y_{\mathrm{O} 2,2}-Y_{\mathrm{O}}\right) / W_{\mathrm{O}} v_{\mathrm{O}}}{Y_{\mathrm{F}, 1} / W_{\mathrm{F}} v_{\mathrm{F}}+Y_{\mathrm{O} 2,2} / W_{\mathrm{O}} v_{\mathrm{O}}}
$$

ここで, $Y$ は質量分率， $W$ は分子量， $v$ は化学量論時 のモル数である. 添字 $\mathrm{O}, \mathrm{F}$ は，酸化剂と燃料それぞ れを示す. $Z$ は混合層の酸化剂側が 0 , 燃料側が 1 に なる. 酸化剤ダクト出口での質量分率を $Y_{\mathrm{O} 22}$, 燃料ダ クト出口での質量分率 $Y_{\mathrm{F}, 1}$ とする．このとき，火炎構 造を特徽付ける火炎位置は, 以下の stoichiometric

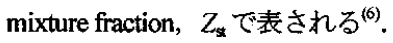

$$
Z_{\mathrm{st}}=\left(1+\frac{Y_{\mathrm{F}, 1} W_{\mathrm{O}} v_{\mathrm{O}}}{Y_{\mathrm{O}_{2}, 2} W_{\mathrm{F}} v_{\mathrm{F}}}\right)^{-1}
$$

$2 \cdot 3$ 数値計算手法 本研究では, 数值計算手法 として，西岡らが開発した 1 次元対向流火炎の計算 コード $\mathrm{CFF}^{(18)}$ を用いた。本計算コードは Sandia

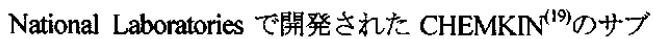
ルーチンを用い詳細な化学反応機構を用いた解析を行 うことができる。本研究では，本コードを用いて，

Flame-controlling continuation method から消炎条件を特 定した. 支配方程式, 解法などの詳細は文献(18)を参 照. 支配方程式中の DME の反応機構は 351 種類の素 反応と 80 種類の化学種を含んだ Curran らの詳細反応 機構 ${ }^{(20)}$ を用いた．また，火炎温度の算出のための平衡 計算には Reynolds などによって開発された STANJAN に基づく EQUIL ${ }^{(19)}$ を用いて計算した，さらに，本研究 で用いた各熱物性值および輸送係数は CHEMKIN から 算出した.

$2 \cdot 4$ 混合気の設定 本研究では燃料に DME と $\mathrm{C}_{3} \mathrm{H}_{8}$ を用いて， 2 種類の実験により消炎に及ぼす平衡 温度，火炎構造の影響を調べた。 希釈剤として窒素 $\mathrm{N}_{2}$ を用い，消炎実験は以下の手順で行った，すなわち， 実験 I は消炎に及ぼす平衡温度の影響を調べるために， 火炎構造を一定にし，平衡温度を変化させて消炎条件 を特定した．実験 Пは消炎に及ぼす火炎構造の影響を 調べるために，平衡温度を一定にし，火炎構造を変化 させて消炎条件を特定した.

\section{3. 結果及び考寮}

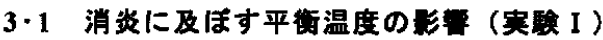

まず，本研究では DME と $\mathrm{C}_{3} \mathrm{H}_{8}$ を用いて火炎構造を一 定 $\left(Z_{\mathrm{s}}\right.$ を一定 $) に し ，$ 平衡温度を変化させた場合の消炎 特性を調べた， $Z_{\mathrm{s}}$ を一定にするため，図 1 に示寸酸化 剂側および燃料側に，それぞれの窒素量 $\mathrm{N}_{2}$ を $Y_{\mathrm{F} .1} / Y_{022}=$ 一定になるように調節して， $Z_{\mathrm{a}}$ が 0.1 になる ように組成を特定した.

図 2(a)に， $Z_{\mathrm{s}}=0.1$ の場合の酸化剂側の酸素の質量分

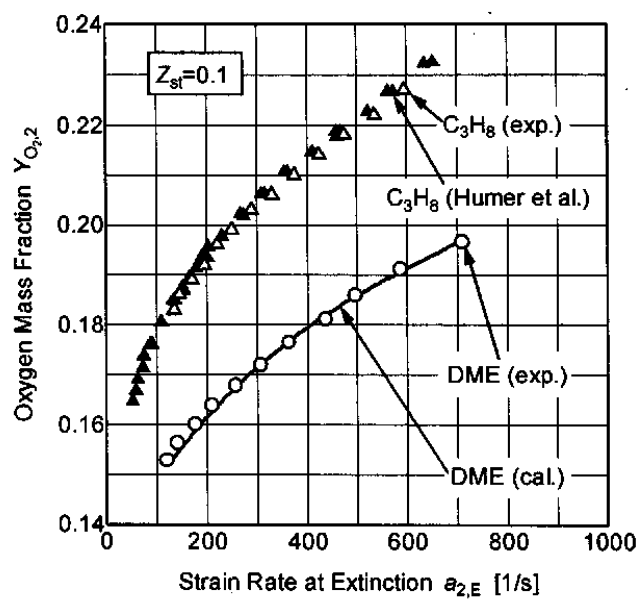

(a) Oxygen Mass Fraction, as a function of the Strain Rate at Extinction

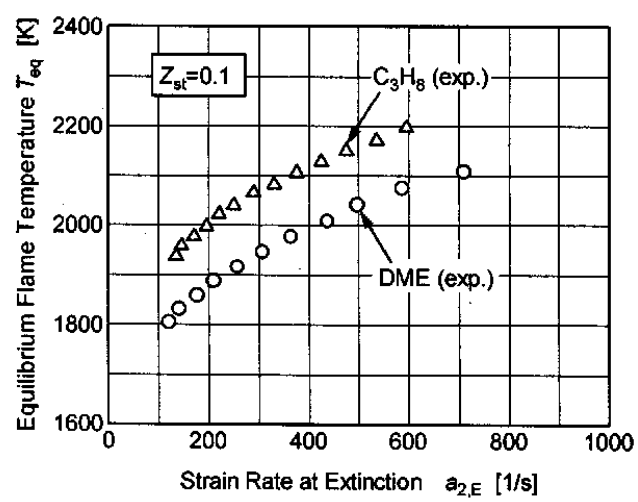

(b) Equilibrium Flame Temperature, as a function of the Strain Rate at Extinction

Fig. 2 Oxygen Mass Fraction and Equilibrium Flame Temperature, in the oxidizer stream, as a function of the Strain Rate at Extinction

率 $Y_{02,2}$ と, 消炎時の火炎伸張率 $a_{2 \mathrm{E}}$ の関係を, $\mathrm{C}_{3} \mathrm{H}_{8}$ に 関する Humer らの実験結果(9)および計算結果とともに 示寸，また，図 2(b)には，組成を基に平衡計算から求 めた平衡温度 $T_{\mathrm{eq}}$ と, 図 2(a)の実験結果に対応した消 炎時の火炎伸張率 $a_{2 \mathrm{E}}$ の関保を示す。図 2(a)分ら, $\mathrm{C}_{3} \mathrm{H}_{8}$ の本実験結果を Humer らの実験結果と比較する と，両者の実験結果はよく一致することから，本実験 の結果は再現性を有し一般性があると考えられる. DME の実験結果と計算結果を比較するとよく一致す ることが分かる.このことから $Z_{\mathrm{s}}=0.1$ の場合, Curran らの反応機構は DME の消炎をよく再現していること が分かる. また, 図 2(a)から, 酸素濃度の低下にとも 
ない, DME, $\mathrm{C}_{3} \mathrm{H}_{8}$ ともにより低い伸張率で消炎に至 ることが分かる.これは図 2(b)から分かるように, $Y_{022}$ の減少に伴い平衡温度が下がることで, 化学反忘 の特性時間 $\tau_{\mathrm{c}}$ が長くなり, ダムケラー数 $D a$ は相対的 に小さくなる.これにより消炎しやすくなったものと 推察される.このことから, 火炎構造が一定の場合, 平衡温度は消炎特性に影響を及ぼすと言える,さらに, $\mathrm{DME}$ と $\mathrm{C}_{3} \mathrm{H}_{8}$ の消炎条件を比較すると, 酸素の質量分 率が等しい場合, または同一平衡温度の場合, DME より $\mathrm{C}_{3} \mathrm{H}_{8}$ の方がより低い伸張率で消炎に至る.これ により, DME は $\mathrm{C}_{3} \mathrm{H}_{8}$ よりも消资しにくいことが分か る.

3.2 消炎に及ほす火桨檴造の影霎（英験 II）次に, 本研究では, DME と $\mathrm{C}_{3} \mathrm{H}_{8}$ を用いて平衡温度を一定に し， $Z_{\mathrm{s}}$ を変化させた場合の消炎特性を調べた. 本研究 ではまず，燃料側に窒素 $\mathrm{N}_{2}$ を添加して平衡温度 $T_{\text {星を }}$ 変化させた 5 種類の基淮混合気を作成した. 表 1 に基 準混合気の組成と平衡温度を示す。

基準混合気に対して平衡温度を一定にして $Z_{\mathrm{s}}$ を変 化させるため, 酸化剤側の窒素を取り除き（酸素富加 な状態)，燃料側に酸化剤側からの窒素を添加するこ とで, 火炎位置において, 表 1 の各混合気の組成が保 持される.この場合，各成分の流量はそれぞれ以下の 式で表される.

$$
\begin{array}{ll}
\frac{Q_{\mathrm{N}_{2}, \mathrm{O}}}{Q_{\mathrm{o}}}+\frac{Q_{\mathrm{N}_{2}, \mathrm{~F}}}{3 Q_{\mathrm{F}}}=\text { constant } & \text { for DME } \\
\frac{Q_{\mathrm{N}_{2}, \mathrm{O}}}{Q_{\mathrm{O}}}+\frac{Q_{\mathrm{N}_{2}, \mathrm{~F}}}{5 Q_{\mathrm{F}}}=\text { constant } & \text { for } \mathrm{C}_{3} \mathrm{H}_{8}
\end{array}
$$

ここで， $Q_{\mathrm{F}} ， Q_{\mathrm{O}}$ はそれぞれ燃料と酸化剤の体積流量 であり， $Q_{\mathrm{N} 2 \mathrm{~F}}, Q_{\mathrm{N} 2 \mathrm{O}}$ はそれぞれ燃料または酸化剤側の 窒素流量である、ここで, 酸素濃度が空気より多い酸 化剂を用いた燃焼は「酸素富加燃焼」と定義される。 同一組成の場合, 酸化剂側の酸素濃度（酸素富加な状 態）が増加すると，より Zが増加することから，同 一組成の火炎に対して $Z_{\mathrm{s}}$ は酸素富加燃焼の程度を表 寸指標となる。

図 3 に火炎温度を一定のまま $Z_{\text {s }}$ 変化させた場合 の消炎時の火炎伸張率 $a_{2, \mathrm{E}}$ の関係を, DME の実験結果

Table 1 Flame considered for Experiment II

\begin{tabular}{l|c|c}
\hline Name & Compositions & $T_{\text {eq }}[\mathrm{K}]$ \\
\hline DN 1 & $\mathrm{DME}+3 \mathrm{~N}_{2}+3\left(\mathrm{O}_{2}+3.76 \mathrm{~N}_{2}\right)$ & 2109 \\
\hline $\mathrm{DN} 2$ & $\mathrm{DME}+4 \mathrm{~N}_{2}+3\left(\mathrm{O}_{2}+3.76 \mathrm{~N}_{2}\right)$ & 2050 \\
\hline $\mathrm{DN} 3$ & $\mathrm{DME}+5 \mathrm{~N}_{2}+3\left(\mathrm{O}_{2}+3.76 \mathrm{~N}_{2}\right)$ & 1992 \\
\hline PN 1 & $\mathrm{C}_{3} \mathrm{H}_{8}+2 \mathrm{~N}_{2}+5\left(\mathrm{O}_{2}+3.76 \mathrm{~N}_{2}\right)$ & 2193 \\
\hline PN 2 & $\mathrm{C}_{3} \mathrm{H}_{8}+3 \mathrm{~N}_{2}+6\left(\mathrm{O}_{2}+3.76 \mathrm{~N}_{2}\right)$ & 2152 \\
\hline
\end{tabular}

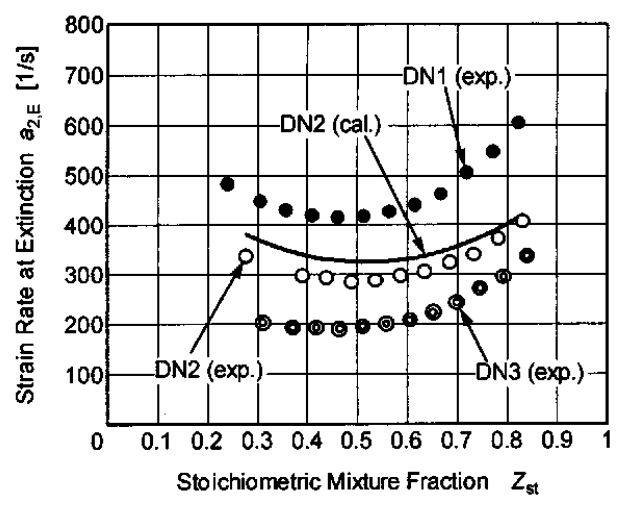

(a) DME

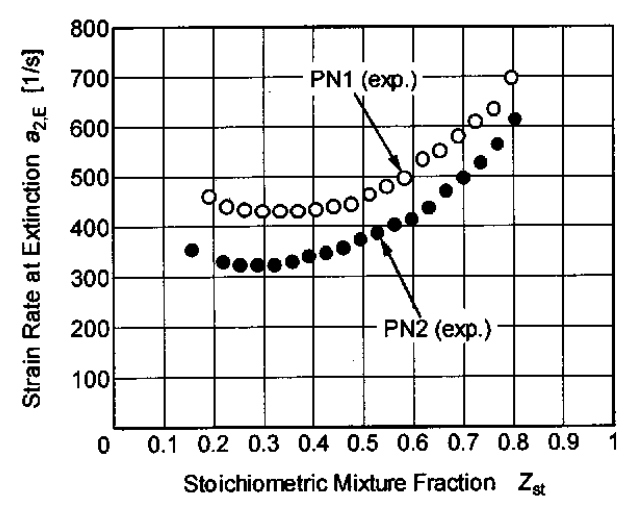

(b) $\mathrm{C}_{3} \mathrm{H}_{8}$

Fig. 3 Strain Rates at Extinction as a function of Stoichiometric Mixture Fraction, all with the same Equilibrium Flame Temperature

（図 3(a)）と $\mathrm{C}_{3} \mathrm{H}_{8}$ の実験結果（図 3(b)）および基準混 合気 DN2 の計算結果とともに示寸，図3(a)から，DN2 火炎の実験結果と計算結果を比較すると, 両者は一致 していることが分かる、このことから，Curran らの反 応機構は DME の消炎をよく再現していることが分か る. また図 3(a)(b)加ら， $\mathrm{C}_{3} \mathrm{H}_{8}$ では $Z_{\mathrm{s}}$ の増加にともな い $a_{2, \mathrm{E}}$ はほぼ単調に增加するが, DME では $a_{2 \mathrm{E}}$ は $Z_{\mathrm{s}}=0.5$ 付近まで若干減少し, その後, 大きく増加して いる.このことから, 両燃料とも酸素富加燃焼により, 耐消炎特性は向上するが，この傾向は $\mathrm{C}_{3} \mathrm{H}_{8}$ でより顕 著になることが分かる.

図 4 に DN2 火炎のときの $Z_{\mathrm{s}}=0.277,0.561,0.832$ の 消炎直前の火炎温度と主な化学種のモル分率分布を示 す. 図 4 から $Z_{\mathrm{s}}$ が増加するにつれて，火炎はよどみ 面に向かって移動し，さらには酸化剂側から燃料側に 移動することが分かる．また，図 4 から，Z祘が増加す るにつれて (酸素富加燃焼), 高温帯内の酸素の相対 


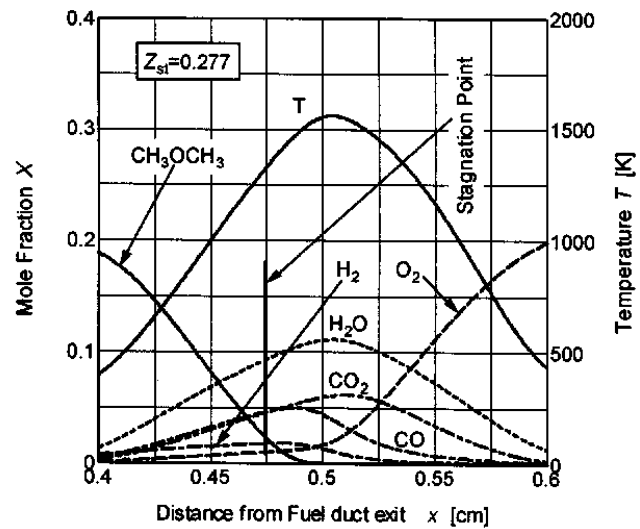

(a) diluted DME/air $\left(Z_{\mathrm{sc}}=0.277\right)$ $a_{2}=344[1 / \mathrm{s}]$

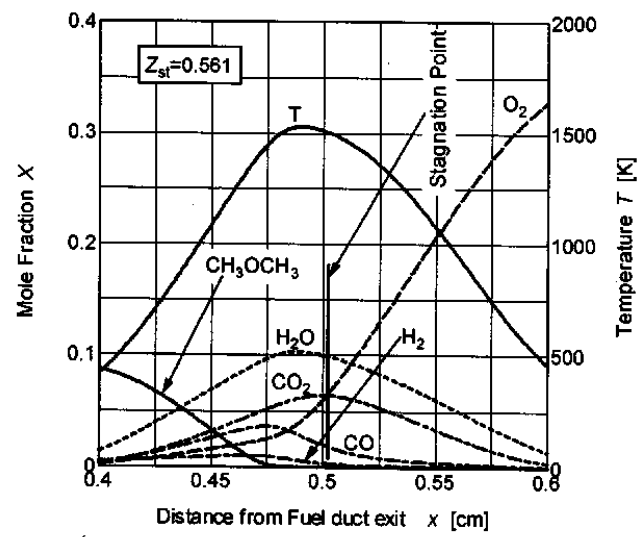

(b) diluted DME/oxygen-enriched $\operatorname{air}\left(Z_{\mathrm{ss}}=0.561\right)$ $a_{2}=308[1 / \mathrm{s}]$

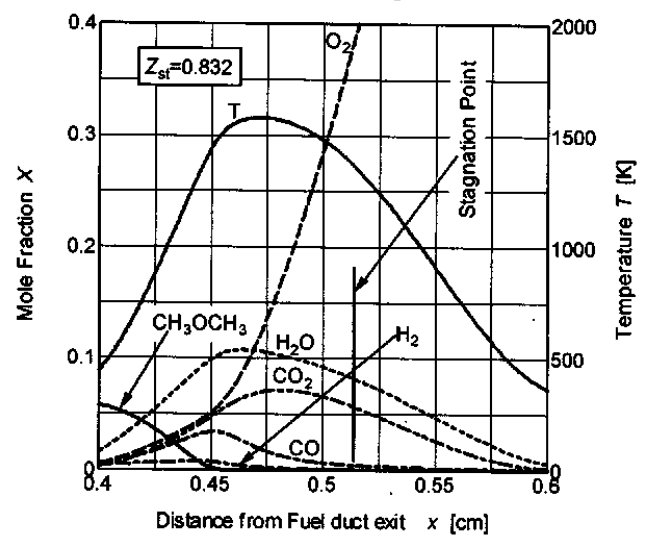

(c) diluted DME/oxygen $\left(Z_{\mathrm{st}}=0.832\right)$ $a_{2}=408[1 / \mathrm{s}]$

Fig. 4 Major Species Profiles and Temperature near Extinction for DME flames (DN2 flame)

量は増加し, 逆に DME の量は減少することが分かる. 以上のことから酸化剤側の酸素濃度を増やす（酸素富

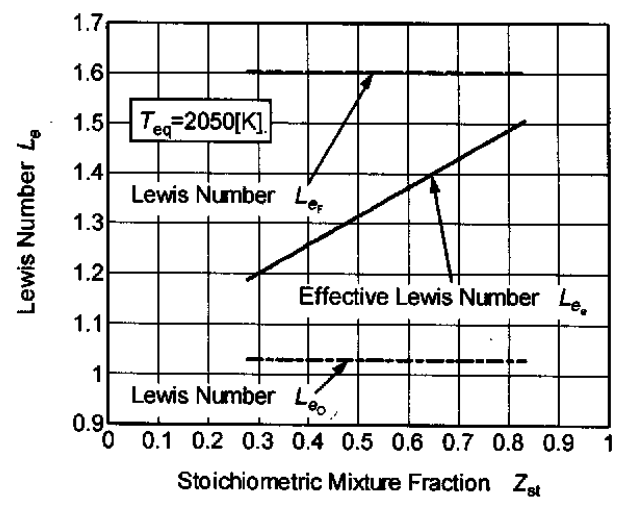

Fig. 5 Lewis Number and Effective Lewis Number, as a Function of Stoichiometric Mixture Fraction, All with Same Equilibrium Flame Temperature for DME (DN2 Flame)

加）ことで $Z_{\mathbf{s}}$ は増加（火炎が燃料側に移動）し，火

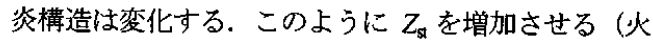
炎を然料側に移動させる）ことで，図 3 に示すように 耐消炎特性の高い火炎が形成できることが分かる．す なわち火资組成が一定の場合でも酸素富加燃焼により 耐消炎特性を向上させることができる.

以下では，図 3 に見られるような $Z_{\mathrm{st}}$ の変化による 消炎特性の変化（ $a_{2, \mathrm{E}}$ の変化）に関してダムケラー数, ルイス数及び，詳細な火炎反応の観点から段階的に消 炎機構を検討した.

表 1 に示す各基準混合気では，火炎位置での組成が 一定となることから，化学反応の特性時間 $\tau_{\mathrm{c}}$ 及び臨界 ダムケラー数 $D a_{\mathrm{q}}$ (火炎の耐消炎特性值) は一定であ ると仮定すると， $Z_{\text {s }}$ の変化による $a_{2 \mathrm{E}}$ の変化は説明で きない，この場合，何らかの付加的な効果により， $\tau_{\mathrm{c}}$ 及び (又は) $D a_{\mathrm{q}}$ が変化したものと推察される. この 要因として本研究ではまず, 分子レベルの熱・物質拡 散の不均衡 (Preferential diffusion) に起因するルイス 数効果 ${ }^{(6)(7)}$ を考える.

図 5 に DN2 火炎 $\left(T_{\mathrm{eq}}=2050[\mathrm{~K}]\right)$ に対して， 化させたときの燃料側のルイス数 $L e_{\mathrm{F}}$, 酸化剂側のル イス数 $L e_{0}$ 変化をそれぞれ示す. 図 5 から，ルイス数 $L e_{\mathrm{F}}, L e_{\mathrm{O}}$ は, $Z_{\mathrm{s}}$ の増加により変化しないことから燃料 側, 酸化剂側の単独のルイス数効果では現象を説明で きない，図4 から分かるように，消炎近傍では，燃料， 酸化剂は完全には消費されず, 反応帯を通過し，拡散 火炎内に「予混合燃焼領域」のが形成される。この領 域での現象は，然料側，酸化剂側それぞれ単独のルイ ス数では説明できず，「予混合燃焼領域」における不 足成分を考虑した重み付き有効ルイス数を考虑する必 要があることが指摘されている(21)(23). 本研究では以下 
で有効ルイス数効果により検討する. Kim と Lee の理 論的研究 ${ }^{(23)}$ から, 消炎近傍の予混合燃焼領域に適用で きる有効ルイス数 $L e_{\mathrm{e}}$ は, 以下の式で示される.

$$
L e_{\mathrm{e}}=\frac{L e_{\mathrm{F}}+A_{\mathrm{F}} L e_{0}}{1+A_{\mathrm{F}}}
$$

式中のパラメータ $A_{\mathrm{F}}$ は, 次式で定義される.

$$
A_{\mathrm{F}}=v^{\prime} \frac{Y_{\mathrm{F}}}{Y_{\mathrm{O}}}
$$

ここで， $v^{\prime}$ は化学量論での酸化剤と燃料の質量比 (DME の場合は，96/46=2.087)，Y, $Y_{\mathrm{F}}$ はをそれぞれ燃 料の質量分率，酸化剤の質量分率である.

図 5 に DN2 火炎 $\left(T_{\mathrm{eq}}=2050[\mathrm{~K}]\right)$ に対して， $Z_{\mathrm{g}}$ を変 化させたときの有効ルイス数 $L e_{\mathrm{e}}$ の変化を示す. 図 5 から, 有効ルイス数 $L e_{\mathrm{e}}$ は， $Z_{\mathrm{s}}$ の増加にともない増加 する.これは $Z_{\mathrm{s}}$ が増加すると燃料側の燃料浱度が低 下するため, $L e_{\mathrm{c}}$ の算出において, 燃料側のルイス数 $L e_{\mathrm{F}}$ の重みが増加するためである. Z Z 堌加による有 効ルイス数 $L e_{\mathrm{e}}$ の増加は相対的に物質拡散より熱拡散 の方が大きくなり消资しやすくなることを意味する. これは, 図 3 の実験結果と矛盾するため, 本実験結果 を式(7)で定義される有効ルイス数では説明できないこ とが分かる.これは式(7)の導出において, 火炎位置の 変化が考虑されていないためと考えられる.すなわち， 同一組成の火炎で $Z_{\text {s }}$ が変化する場合には，「予混合燃 焼領域」を考虑したルイス数効果の議論は適用できな いと言える.このことから，Zょが変化する場合には， 詳細な素反応に基づいて議論する必要がある. そこで 以下では，詳細化学反応を考慮した計算結果から消资 特性を検討する.

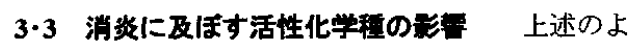
うに平衡温度が一定の場合でも $Z_{\mathrm{s}}$ すなわち, 火炎構 造の変化が消炎特性に影響を及ぼすことが分かる，以 下ではこのメカニズムについて活性化学種 $\mathrm{OH}$ 基生成 の観点から考察する.

図 6 に DN2 火炎のときの $Z_{\mathrm{x}}=0.277,0.561,0.832$ の 場合, 消炎直前の $\mathrm{OH}$ 基の反応速度と火炎温度の変化 を示す. 図6から，Z増加とともに，OH 基の生成 場所が酸化剂側から然料側に移動していることが分か る.ここで特に消炎特性に影響を及ぼす以下の反态に 着目する.

$$
\mathrm{H}+\mathrm{O}_{2} \rightarrow \mathrm{OH}+\mathrm{O}
$$

反応 Rl は活性化エネルギーが大きいことから, (1) 高い温度と（2）高い酸素濃度を必要とする. 図 6(a)加ら $Z_{\mathrm{s}}=0.277$ の場合, 反応 $\mathrm{R} 1$ の最大值の場所 （以下では radical pool）は最高温度点より酸化剤側に 位㯰している.これは図 4(a)から分かるように最高温

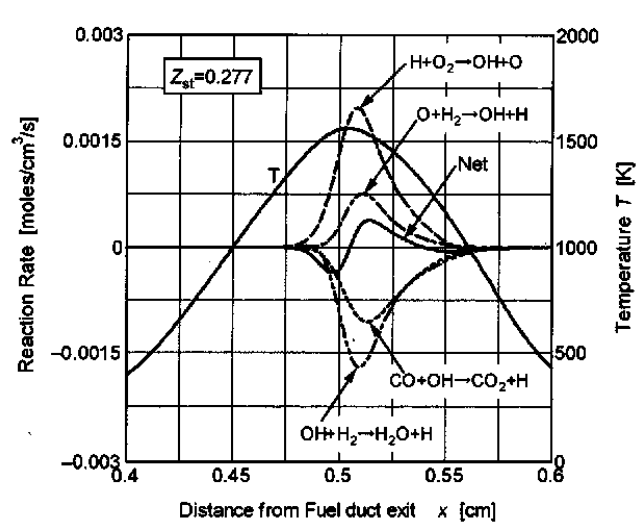

(a) diluted DME/air $\left(Z_{\mathrm{s}}=0.277\right)$ $a_{2}=344[1 / s]$

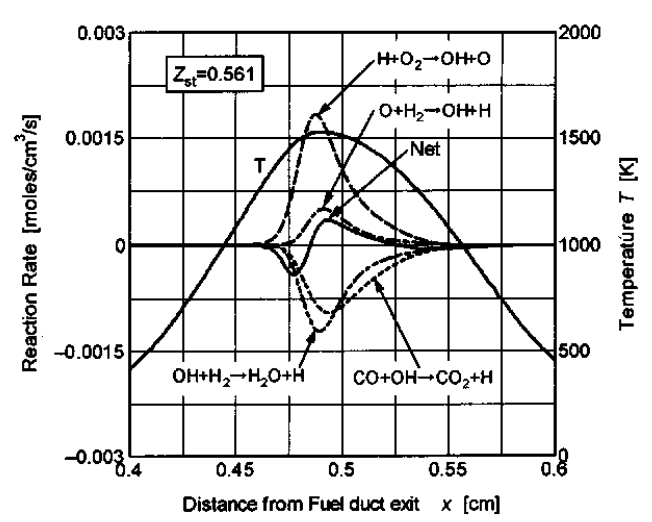

(b) diluted DME/oxygen-enriched $\operatorname{air}\left(Z_{\mathbf{s}}=0.561\right)$ $a_{2}=308[1 / \mathrm{s}]$

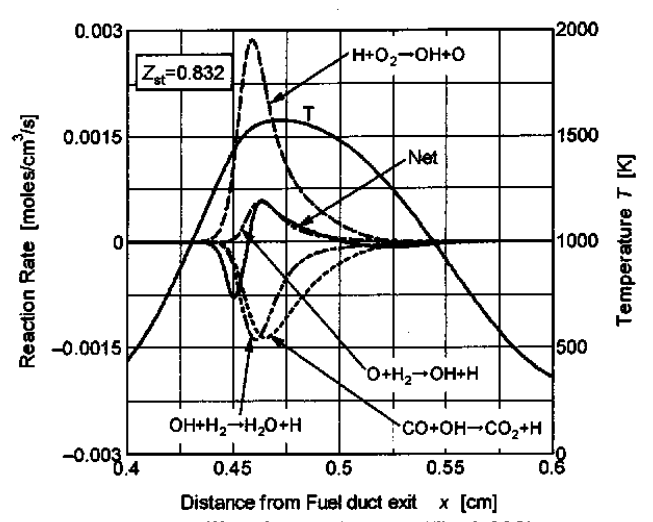

(c) diluted DME/oxygen $\left(Z_{\mathrm{s}}=0.832\right)$ $a_{2}=408[1 / \mathrm{s}]$

Fig. 6 Reaction Rate Profiles for the Primary Radical Production reactions and Temperature for DME Flames（DN2 flame）

度点の酸素浱度が少ないためである. 一方, $Z_{\mathrm{s}}$ を増加 させると図 4(b)から分かるように最高温度の場所での 


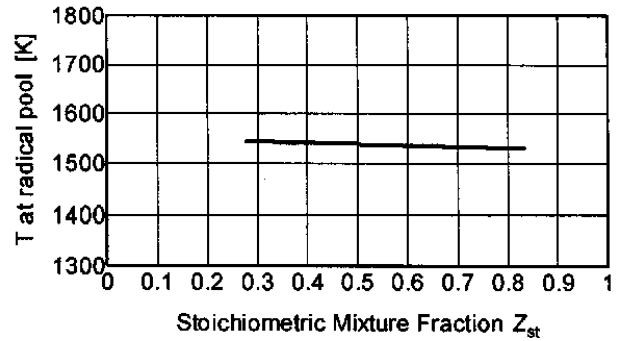

Fig. 7 Temperature at the Radical Production Zone for Flames near Extinction

酸素濃度が増加するため, radical pool が最高温度の場 所に近づく（図 6(b)， $Z_{\mathrm{s}}=0.561$ ）。しかしながら $\mathrm{OH}$ 基 の生成速度は減少し, 図 3(a)のように火炎仕若干消炎 しやすくなっている. 図 3(b)から $\mathrm{C}_{3} \mathrm{H}_{8}$ ではこのよう な傾向が少ないことから，これは含酸素燃料特有の現 象と考えられる.すなわち, DME は燃料中に酸素を 有するため, 図 4(b)から分かるように, 高温度領域で の燃料莀度が相対的に低下することで, 反応 R1 も減 少したものと考えられる.

さらに $Z_{\mathrm{st}}$ を増加させると高温度の領域は広くなり， radical pool は燃料側に移動するが, 最高温度の場所と は一致している (図 6(c)， $Z_{\mathrm{s}}=0.832$ )。 $\mathrm{OH}$ 基の生成速 度は大きく増加し，図 3(a)加分かるように火炎は消 炎しにくくなっている.これは，図 4(c)から燃料中の 酸素濃度低下を上回る酸素濃度が高温度領域に存在す るためと考えられる.

本研究ではこのような活性化学種の生成場所 (radical pool) と火炎位置（最高温度点）の相関が消 炎特性に影響を及ぼしていると考え，消炎時における 反応 R1 の温度特性を調べた. 図 7 に消炎近傍での radical pool における火资温度を示寸. 図 7 から，Zょ 関係なくほぼ $1550 \mathrm{~K}$ の一定值を示討ことが分かる. すなかち，DME 火炎では radical pool での火炎温度が $1550 \mathrm{~K}$ 以下になった場合，消炎に至ることが分かる. $Z_{\text {s }}$ が小さい場合, 図6に見られるように radical pool と 火炎位置（最高温度点）に差異があるため radical pool での火资温度が $1550 \mathrm{~K}$ 付近で消炎を迎える場合, 消 炎時の最高温度はこれより高い温度で消炎に至る.よ り高い火炎温度で消炎を迎えることから，相対的に消 炎しやすい火炎になっている。 一方， $Z_{\mathrm{st}}$ が増加し， 0.8 近傍では, radical pool での火炎温度と最高温度が 一政するため，より低い温度まで消炎しないことから， 相対的に消炎しにくい火炎になったものと推察される.

\section{4. 結}

本研究では, 火炎構造を一定にして平衡温度を変化 させた場合と, 平衡温度を一定にして火炎構造を変化 させた場合の 2 種類の実験を行い，DME 拡散火资お よび $\mathrm{C}_{3} \mathrm{H}_{8}$ 拡散火炎の消炎特性を調へ，以下の結果を 得た.

火炎構造を一定にし，平衡温度を変化させて消炎特 性を調べた夷験において,

(1) DME の実験結果と計算結果を比較すると, $Z_{\mathrm{z}}=0.1$ の場合, Curran らの反応機構は, DME の消炎を よく再現していることが分かった。

（2）酸素漲度の低下にともない， DME， $\mathrm{C}_{3} \mathrm{H}_{8}$ ともに 低い伸張率で消炎した，すなわち，酸素浱度の低 下によって平衡温度が下がり，消炎しやすくなっ たものと推察される.このことから, 火炎構造が 一定の場合，平衡温度は消炎特性に影響を及ぼす ことが分かった。

(3) DME と $\mathrm{C}_{3} \mathrm{H}_{8}$ の消炎条件を比較すると, 酸素の質 量分率が等しい場合, または同一平衡温度の場合, DME より $\mathrm{C}_{3} \mathrm{H}_{8}$ の方がより低い伸張率で消炎に至 る.これにより, DME は $\mathrm{C}_{3} \mathrm{H}_{8}$ よりも消炎しにく いことが分かった.

平衡温度を一定（組成を一定）にし, 火炎構造を変 化させて消炎特性を調べた実験において，

(4) $\mathrm{C}_{3} \mathrm{H}_{8}$ では $Z_{8}$ の増加にともない $a_{2 \mathrm{E}}$ はほほぼ単調に増 加するが, DME では $a_{2, E}$ は $Z_{\mathrm{\alpha}}=0.5$ 付近まで若干 減少し，その後，大きく増加した。 このことから， 両燃料とも酸素富加燃焼により，耐消炎特性は向 上するが，この傾向は $\mathrm{C}_{3} \mathrm{H}_{8}$ でより顕著になるこ とが分かった. すなわち火资組成が一定の場合で も酸素富加燃焼により耐消炎特性を向上させるこ とができる.

（5）詳細化学反応を考虑した数值解析により, 消炎特 性に及ぼす活性化学種の影響を調べた。その結果, 活性化学種の生成場所（radical pool）と火炎位置

(最高温度点)の相関が消炎特性に影響を及ぼし ていることが分かった。

本研究の一部は平成 18 年度科学研究費補助金若手研 究(B)(No.16760159), 造船学術研究推進機構の助成に より行われた。本研究の遂行にあたり，UCSDの Seshadri 教授, Seiser 博士には実験全般をアドバイス いただき，筑波大学の西岡先生には数值解析コードを 
ご提供いただきました。また，千葉大学の森吉先生， 茨木大学の金野先生, 陳先生には DME に関する貴重 なアドバイスをいただきました，付記して感謝いたし ます。

\section{文献}

(1) Heywood, J.B. "Internal Combustion Engine Fundamentals". McGraw-Hill Science Engineering, (1988), 930p.

(2) Troy, A.S., Rondney, L.B. and Howard, L.G. "Dimethyl ether (DME) as an alternative fuel". Journal of Power Sources. vol.156, (2006), p.497511.

(3) Fleisch, T.H. and Meuer, P.C. "DME : The Diesel Fuel for the 21 th Century ?". Proc. Conf. Program Int. Congress Engine and the Environment. Graz, Austria, (1995), p.24-25.

(4) Chen, Z., Konno, M. and Kajitani, S. "Performance and Emissions of DI Compression Ignition Engines Fueled with Dimethyl Ether (Performance and Emissions in Retrofitted Engines)". JSME Internal Journal Series B. vol.43, no.1, (2000), p.82-88.

(5) Kajitani, S. "A Study of Low Compression Ratio Diesel Engines Operated with Neat Dimethyl Ether (DME)". JSME TED Newsletter. no.42, (2004), 12p.

(6) F.A., Williams. "Progress in knowledge of flamelet structure and extinction". Progress in Energy and Combustion Science. vol.26, (2000), p.657-682.

(7) Liñán, A. "The asymptotic structure of counterflow diffusion flames for large activation energies". Acta Astronaut. 1, (1974), p.1007-1039.

(8) Tsuji, H. "Counterflow Diffusion Flames". Progress in Energy and Combustion Science. vol.8, (1982), p.93-119.

(9) Humer, S., Seiser, R. and Seshadri, K. "Nonpremixed and Premixed Extinction and Autoignition of $\mathrm{C}_{2} \mathrm{H}_{4}, \mathrm{C}_{2} \mathrm{H}_{6}, \mathrm{C}_{3} \mathrm{H}_{6}$ and $\mathrm{C}_{3} \mathrm{H}_{8}$ ". Twenty-Ninth Symposium (International) on Combustion. The Combustion Institute. (2002), p.1597-1604.

(10) Chen, R. and Axelbaum, R.L. "Scalar dissipation rate at extinction and the effects of oxygen-enriched combustion". Combustion and Flame. vol.142, (2005), p.62-71.

(11) Du, J. and Axelbaum, R.L. "The effects of flames structure on extinction of $\mathrm{CH}_{4}-\mathrm{O}_{2}-\mathrm{N}_{2}$ diffusion flames". Twenty-Sixth Symposium (International) on Combustion. The Combustion Institute, (1996), p.1137-1142.

(12) Isizuka, S. and Tsuji, H. "An Experimental Study of Effect of inert Gases on Extinction of Laminar Diffusion Flames". Eighteenth Symposium (International) on Combustion. The Combustion Institute, (1981), p.695-703.

(13) Puri, I.K. and Seshadri, K. "Extinction of Diffusion Flames Burning Diluted Methane and Diluted Propane in Diluted Air". Combustion and Flame. vol.65, (1986), p.137-150.

(14) Poola, R.B., Ng, H.K., Sekar, R.R., Baudino, J.H. and Colucci, C.P. "Utilizing Intake-Air OxygenEnrichment Technology to Reduce Cold-Phase Emissions". SAE Technical Paper 952420, Warrendale, PA, (1995).

(15) C.E., Baukal, Jr., "Oxygen-Enhanced Combustion". CRS Press, 1998, 369p.

(16) Seiser, R. "Ignition and Extinction of Nonpremixed Flames". Technical University of Graz, (2000), Ph.D Thesis.

(17) Seshadri, K. and Williams, F.A. "Laminar Flow between Parallel Plates with Injection of a Reactant at High Reynolds Number". International Journal of Heat Mass Transfer. vol.21, (1978), p.251-253.

(18) Nishioka, M., Law, C.K. and Takeno, T. "A FlameControlling Continuation Method for Generating SCurve Responses with Detailed Chemistry". Combustion and Flame. vol.104, (1996), p.328-342.

(19) Kee, R.J., Rupley, F.M. and Miller, J.A., et al. CHEMKIN Collection, Release 3.7, Reaction Design, Inc., San Diego, CA, (2003).

(20) Curran, H.J., Fischer, S.L. and Dryer, F.L. "The Reaction Kinetics of Dimethyl Ether. : LowTemperature Pyrolysis and Oxidation in Flow Reactions". International Journal of Chemical Kinetics. vol.32, (2000), p.741-759.

(21) Chen, R.-H., Mitchell, G.B. and Rooney, P.D. "Diffusive-Thermal Instability and Flame Extinction in Nonpremixed Combustion". TwentyFourth Symposium (International) on Combustion. The Combustion Institute. (1992), p.213-221.

(22) Chaos, M. and Chen, R.-H. "An Experimental Study of Pulsating Instability in near-limit Laminar Nonpremixed flames". Combustion Science and Technolnology. vol.176, (2004), p.1191-1215.

(23) Kim, J.S. and Lee, S.R. "Diffusional-thermal instability in strained diffusion flames with unequal Lewis numbers". Combust. Theory Modelling. vol.3, (1999), p.123-146. 